\title{
IMPLEMENTATION OF AMONG SYSTEM A3 (ASAH, ASIH, ASUH) IN PLANTING THE VALUE OF CHARACTERS IN EARLY CHILDHOOD
}

\section{Siti Wahyuningsih, Nurul Kusuma Dewi, Ruli Hafidah}

Universitas Sebelas Maret

siti_w@staff.uns.ac.id

\begin{tabular}{l} 
Article History \\
\hline accepted 09/07/2018 \\
approved 01/08/2018 \\
published 17/09/2018
\end{tabular}

Keywords

Among Systems,

Character, Early

Childhood

\begin{abstract}
This activity was carried out in Gugus Mawar, Karanganyar Regency. The service activity aims to provide training to preschool (PAUD) and kindergarten teachers of Gugus Mawar, Karanganyar about the application of the among system (asah, asih, asuh) to instill character valuesin early childhood. The training participants consisted of 20 teachers of preschool and kindergarten in Gugus Mawar, Karangannyar. The training was carried out in three stages, namely (1) Preimplementation, (2) Implementation, and (3) Monitoring and Evaluation. The training material were (1) material about the concept of the among system, early childhood learning, and the character valuesthat must be inculcated in early childhood; (2) learning device material that applies among systems to instill the character values of early childhood; (3) the implementation of among system in learning to instill the character values of early childhood in their respective schools. The material given during the training resulted in preschool and kindergarten teachers in Gugus Mawar, Karangannyar being able to develop learning instrument, carry out learning, and instill character valuesin early childhood by implementing the among (asah, asih, asuh) systems.
\end{abstract}

Social, Humanities, and Education Studies (SHEs): Conference Series https://jurnal.uns.ac.id/shes 


\section{PENDAHULUAN}

UU Nomor 20 Tahun 2003 tentang Sisdiknas, pasal 3, yang berbunyi: "Pendidikan nasional berfungsi mengembangkan kemampuan dan membentuk watak serta peradaban bangsa yang bermartabat dalam rangka mencerdaskan kehidupan bangsa, bertujuan untuk berkembangnya potensi peserta didik agar menjadi manusia yang beriman dan bertakwa kepada Tuhan Yang Maha Esa, berakhlak mulia, sehat, berilmu, cakap, kreatif, mandiri dan menjadi warga negara yang demokrasi serta bertanggung jawab." Undang-undang Sisdiknas tersebut menjelaskan bahwa pendidikan yang dilakukan di Indonesia menekankan pada karakter bangsa dan nilai karakter ini harus ditanamkan sejak pendidik dini yaitu pada anak usia dini. Penanaman nilai karakter pada anak usia dini dapat dilakukan dengan berbagai cara dan metode, yaitu melalui pembiasaan, pembelajaran, dan teladan atau contoh dari orang dewasa sekitar anak. Pada zaman sekarang ini sudah banyak pergeseran nilai karakter yang ada di masyarakat, bahkan anak-anak usia dini sudah tidak lagi diajarkan nilai-nilai karakter tapi orang tua dan guru sibuk dengan aspek akademik saja. Perkembangan dan pertumbuhan anak usia dini tidak terlepas dari enam aspek perkembangan anak, yaitu: perkembangan nilai agama dan moral, sosial dan emosional, bahasa, kognitif, fisik motorik, serta seni. Keenam aspek perkembangan anak ini saling terintegrasi dan saling mempengaruhi untuk menyiapkan anak di kehidupan selanjutnya. Oleh karena itu, menanmkan karakter sejak usia dini sangat penting, karena akan pembentuk karakter anak pada kehidupan selanjutnya ada pada penanamkan karakter sejak dini. Pada anak usia dini penanaman karakter dapat dilakukan dengan sesuai dengan nilai budaya bangsa Indonesia dimana lingkungan anak tinggal. Cara atau metode ini sudah secara tidak langsung diterapkan dalam kehidupan sehari-hari, yaitu sistem among. Sistem juga dapat diterapkan dalam dunia pendidikan yaitu dimana sikap guru yang berperan sebagai pamong dalam sistem among asah asih asuh (A3). Ki Suratman (1982) menjelaskan bahwa guru memperlihatkan sikap laku among, yaitu: (1) berjiwa kekeluargaan, (2) bersikap manusiawi, (3) arif dan bijaksana, (4) memperlakukan anak sesuai dengan harkat dan martabat kemanusiannya, (5) menempatkan anak sebagai subjek dan obyek dalam proses pendidikan, (6) memperhatikan kodrati anak sesuai dengan tahap-tahap perkembangan raga-jiwanya, (7) selalu siap menjadi teladan dalam segala perilaku berdasarkan nilai-nilai luhur bangsa Indonesia. Sesuai dengan pendapat Ki Suratman diatas dapat dijelaskan bahwa sebelum menanamkan nilai karakter pada anak usia dini, sebagai pendidik atau guru harus memiliki sikap atau nilai karakter terlebih dahulu yang bisa ditanamkan pada anak usia dini. Oleh karena itu, sistem amaong (asah, asih asuh) sangat penting diterapkan pada dunia pendidikan terutama dalam proses pembelajaran untuk menanamkan nilai-nilai karakter pada anak usia dini.

\section{METODE}

Kegiatan pengabdian dilakukan di gugus Mawar, Kabupaten Karanganyar yang terdiri dari 6 TK dan PAUD. Tujuan kegiatan pengabdian bertujuan untuk meningkatkan kemampuan dan keterampilan guru-guru PAUD gugus Mawar, kabupaten Karanganyar dalam melaksanakan pembelajaran yang menanamkan nilai karakter anak usia dini melalui sitem among (asah, asih, asuh). Subjek adalah 20 guru TK dan PAUD gugus Mawar, kabupaten Karanganyar. Kegiatan pengabdian dilakukan dengan beberapa tahapan, yaitu: (1) Pra pelaksanaan; (2) Pelaksanaan; (3) monitoring dan evaluasi. Tahap pra pelaksanaan dilakukan dengan melakukan observasi dan identifikasi lapangan, menyusun konsep pelatihan, dan menyiapkan materi. Tahap pelaksanaan dilakukan dengan kegiatan pelatihan selama 2 hari untuk guru-guru TK dan PAUD gugus Mawar, Kabupaten Karanganyar. Materi yang diberikan pada hari pertama adalah materi tentang konsep sistem among, pembelajaran anak usia dini, 
dan nilai karakter yang harus ditanamkan. Pada hari kedua, guru-guru TK dan PAUD gugus Mawar, Kabupaten Karanganyar diberikan materi perangkat pembelajaran yang menerapkan sistem among untuk menanamkan nilai karakter anak usia dini. Tahap ketiga adalah monitoring dan evalusai. Pada tahap ini guru-guru TK dan PAUD gugus Mawar, Kabupaten Karanganyar menerapkan hasil pelatihan pada sekolah masingmasing dan akan dievalusi hasilnya.

\section{HASIL DAN PEMBAHASAN}

Penanaman nilai karakter pada anak usia dini tidak terlepas dari seluruh aspek perkembangan anak, terutama nilai agama dan moral. Pada masyarakat Indonesia nilai karakter cenderung berhubungan dengan sikap sopan santun dan etika, sedangkan pada anak usia dini nilai karakter mencakup nilai-nilai yang akan ditanamkan pada anak untuk membentuk karakter anak yang lebih baik. Menurut Hidayatullah (2010) pendidikan untuk pembentukan karakter adalah kualitas moral, akhlak atau budi pekerti individu yang merupakan kepribadian khusus yang membedakan dengan individu lain. Menurut Hidayatullah tersebut menjabarkan bahwa karakter yang ditanamkan dan dimiliki olah anak usia dini akan menjadi karateritik yang lebih baik. Nilai karakter yang harus ditanamkan pada anak usia dini sejak pendidikan dini meliputi: religius, jujur, toleransi, disiplin, kerja keras, kreatif, mandiri, demokratis, rasa ingin tahu, cinta tanah air, semangat kebangsaan, menghargai prestasi, komunikatif, cinta damai, gemar membaca, peduli lingkungan, peduli sosial, dan tanggung jawab (Pusat kurikulum, 2010). Nilai karakter yang dijabarkan dalam pusat kurikulum diatas dapat ditanamkan pada anak usia dini melalui pembiasaan kegiatan pembelajaran sehari-hari. Hal ini sesuai dengan pendapat Fudyartanta (2010) menjabarkan bahwa kebiasaan adalah tingkah laku yang diulang-ulang dilakukan dan akhirnya menjadi otomatis, tidak memerlukan pikiran-pikiran lagi, sehingga kebiasaan itu akan mempermudah dan mempercepat tindakan.

Pada pendidikan anak usia dini, pembiasaan dalam menanamkan nilai karakter dapat diintegrasi dalam proses pembelajaran. Dewantara (1977) menjelaskan bahwa pengajaran budi pekerti dilakukan untuk menyokong perkembangan hidup anak-anak, lahir dan batin, dari sifat kodratinya menuju ke arah peradaban dalam sifatnya yang umum. Oleh karena itu, peran guru dalam menanamkan nilai karakter pada anak usia dini melalui kegiatan pembelajaran sangatlah penting. Sesuai dengan Hidayatullah (2010), seorang guru dapat menanamkan nilai karakter pada anak usia dini melalui: keteladanan,penanaman disiplin, pembiasaan, menciptakan suasana yang kondusif, dan integrasi dan internalisasi. Hal tersebut dalam dilakuakan guru selama proses pembelajaran yang menyenangkan bagi anak. Peran guru dalam menanamkan nilai karakter pada anak usia dini melalui pembelajaran yang menyenangkan dapat menerapkan sistem among.

Ki Hadjar Dewantoro (1977) menjelaskan bahwa pembelajaran pada anak usia dini atau yang sering dikenal dengan "Taman Indria/Taman Kanak-kanak" dilaksanakan dengan memberikan kebebasan yang seluas-luasnya kepada anak, selama tidak ada bahaya yang mengancam anak. Pendapat Ki Hajar Dewantoro tersebut menjelaskan bahwa guru berperan sebagai fasilitator bagi proses perkembangan anak. Sedangkan menurut Rahardjo (2009) sistem among berkaitan dengan kata dasar Mong yang mencakup Among, Momong dan Ngemong, biasa disebut "Tiga Mong", yaitu memberikan pengasuhan, perhatian, dan stimulasi pada anak untuk mengembangkan aspek perkembangan anak. Berbagai pendapat diatas dapat ditarik kesimpulan bahwa sistem among dapat diimplikasikan dalam kegiatan pembelajaran untuk menanamkan nilai karakter anak usia dini.

Tahapan penanaman karakter pada anak usia dini dalam pembelajaran berbasis sistem among (asah, asih, asuh) yaitu: 
1. Penyusunan silabus

Guru-guru PAUD dan TK gugus mawar, Kabupaten Karangannyar membuat silabus pembelajaran sesuai dengan kurikulum yang digunakan dimasing-masing sekolah. Kurikulum yang digunakan pada tahun ajaran 2018/2019 adalah kurikulum 2013 atau permendikbud 137 dan 146. Silabus dibuat dengan memetakan lingkup perkembangan anak, nilai karakter yang akan ditanamkan, dan indikator yang akan dicapai oleh anak. Silabus dapat berupa rencana semester dan rencana mingguan yang nanti akan digunakan sebagai standar untuk menyusun rencana pelaksanaan pembelajaran harian.

2. Rencana pelaksanaan pembelajaran harian (RPPH)

Guru-guru PAUD dan TK gugus Mawar, Kabupaten Karangannyar menyusun Rencana pelaksanaan pembelajaran harian (RPPH) dari silabus yang telah dibuat sebelumnya. Pada penyusunan rencana pelaksanaan pembelajaran harian (RPPH) terdiri dari: (1) aspek perkembangan anak yang meliputi aspek nilai agama dan moral, kognitif, bahasa, sosial emosional, fisik motorik, seni; (2) indikator pencapaian perkembangan sesuai dengan setiap aspek perkembangan dan usia anak; (3) nilai karakter yang akan ditanamkan kepada anak usia dini, seperti jujur, religius, mandiri, tanggungjawab, disiplin, dsb disesuaikan dengan kegiatan pembelajaran; (4) penempatan sistem among (asah, asih, asuh) dalam tahapan pembelajaran yang dapat diimplikasikan dalam kegiatan awal, inti, istirahat, dan akhir; (5) metode pembelajaran pembelajaran dalam menanamkan nilai karakter melalui sistem among adalah dengan kegiatan bermain, seperti permainan tradisional, lagu tradisional, game, dsb yang dapat menjadi alat dalam menanamkan nilai karakter selama proses pembelajaran yang menyenangkan; (6) materi pembelajaran dalam menanamkan nilai karakter pada anak usia dini melalui sistem among dikembangkan berdasarkan tema dan nilai karakter yang akan ditanamkan.

Contoh kegiatan pembelajaran yang menanamkan nilai karakter pada anak usia dini dengan menerapkan sistem among (asah, asih, asuh) yaitu: tema profesi dengan sub tema petani dapat menggunakan gerak dan lagu tradisional "gundulgundul pancul" yang memiliki filosofi "sombong atau besar kepala", sehingga melalui gerak dan lagu tradisional "gundul-gundul pancul" ini dapat mengajarkan pada anak bahwa sebagai manusia kita tidak boleh sombong harus rendah hati atas kelebihan yang dimiliki. Kegiatan pembelajaran gerak dan lagu tradisional "gundul-gundul pancul" juga dapat mengajarkan pada anak alat-alat yang digunakan untuk bertani. Selain itu, aspek perkembangan anak juga terstimulasi. Pada contoh pembelajaran diatas, konsep asah dapat diterapkan guru dalam kegiatan awal dan akhir dimana guru dan anak berdiskusi tentang nilai sombong dan rendah hati. Sedangkan konsep asih dapat diterapkan guru dalam memberikan contoh pada perilaku sehari-hari. Konsep asuh dapat diterapkan guru selama proses pembelajaran yaitu mendampingi anak dan menjadi fasilitator dalam menginternalisasi nilai karakter rendah hati pada anak usia dini.

3. Media pembelajaran

Media pembelajaran anak usia dini dapat diambil melalui lingkungan sekitar anak. Media pembelajaran digunakan untuk menyampaikan sesuatu pesan atau informasi. Pada penanaman nilai karakter pada anak usia dini melalui penerapan sistem among (asah, asih, asuh) dapat menggunakan gambar, buku, video, maupun peralatan yang menunjang kegiatan pembelajaran.

4. Penilaian

Penilaian dapat dilakukan oleh guru untuk mengetahui pencapaian perkembangan anak, pengetahuan, dan nilai karakter yang sudah dipahami anak. Penilaian dilakukan dengan menyusun instrumen penilaian (aspek perkembangan anak, indikator ketercapaian, nilai karakter yang ditanamkan); melakukan penilaian pada anak sesuai dengan instrumen yang sudah disusun selama proses pembelajaran 
dari awal sampai akhir pembelajaran; dan guru melakukan evaluasi terhadap perkembangan anak.

Hasil pelatihan pada guru-guru PAUD dan TK Gugus Mawar, Kabupaten Karanganyar menjabarkan bahwa guru-guru PAUD dan TK Gugus Mawar, Kabupaten Karanganyar lebih memahami tentang konsep sistem among (asah, asih, asuh) dan dapat mengimplikasikan dalam perencanaan, pelaksanaan, dan penilaian pembelajaran. Guru-guru PAUD dan TK Gugus Mawar, Kabupaten Karanganyar dapat mengembangkan materi dan kegiatan pembelajaran yang menerapkan sistem among untuk menanamkan nilai karakter pada anak. Guru-guru PAUD dan TK Gugus Mawar, Kabupaten Karanganyar sudah dapat mengembangkan tema dan menyusun kegiatan bermain tidak hanya menggunakan permainan dan lagu tradisional tapi juga sudah mampu memodifikasi kegiatan bermaian yang disesuaikan dengan nilai karakter yang akan ditamankan kepada anak usia dini.

\section{SIMPULAN}

Sistem among (asah, asih, asuh) dapat diterapkan dalam proses pembelajaran untuk menanamkan nilai karakter pada anak usia dini. Penerapan sistem among (asah, asih, asuh) dalam pembelajaran untuk menanamkan nilai karakter pada anak usia dini dilaksanakan selama proses pembelajaran dari kegiatan awal, inti, istirahat, dan penutup. Dalam menerapkan sistem among (asah, asih, asuh) guru berperan sebagai (1) sumber informasi dalam memberikan pengetahuan pada anak usia dini; (2) tauladan atau contoh dalam berbuatan, perkataan, dan berpakaian; dan (3) pendamping dan fasilitator untuk anak selama proses pembelajaran. Dalam penerapan sistem among (asah, asih, asuh) untuk menanamkan nilai karakter pada anak usia dini meliputi bebrapa tahapan, yaitu: penyusunan silabus, penyususan RPPH, menentukan media, serta menyusun dan melakukan penilaian.

Sistem among (asah, asih, asuh) dapat diterapkan dalam proses pembelajaran baik dari pendidikan usia dini sampai pendidikan tinggi. Sistem among (asah, asih, asuh) sesuai dengan teori belajar humanisme dimana sebuah proses pembelajaran memanusiakan manusia dengan peran masing-masing guru dan anak dalam membangun pengetahuan. Sistem among (asah, asih, asuh) tidak hanya digunakan untuk menanamkan nilai karakter saja, tetapi dapat digunakan untuk membangun pengetahuan sehingga akan tercapai generasi bangsa yang memiliki kecerdasan spritual atau religius, emosional, dan intelektual.

\section{DAFTAR PUSTAKA}

Dewantoro, K. H. (1977a). Pendidikan Bagian Pertama. Universitas Sarjana Wiyata Taman Siswa dan Majelis Luhur Taman Siswa.

Fudyartanta, K. (2010). Membangun Kepribadian Dan Watak Bangsa Indonesia Yang Harmonis Dan Integral.Yogyakarta: Pustaka Pelajar.

Hidayatullah, M. F. (2007). Mengantar calon pendidik berkarakter di masa depan. Surakarta: UNS Press.

Pusat Kurikulum. (2010). Pengembangan Pendidikan Budaya Dan Karakter Bangsa. Jakarta: Kementerian Pendidikan Nasional.

Suratman, K.. (1982). Sistem Among. Yogyakarta: Majelis Luhur Persatuan Taman siswa. 